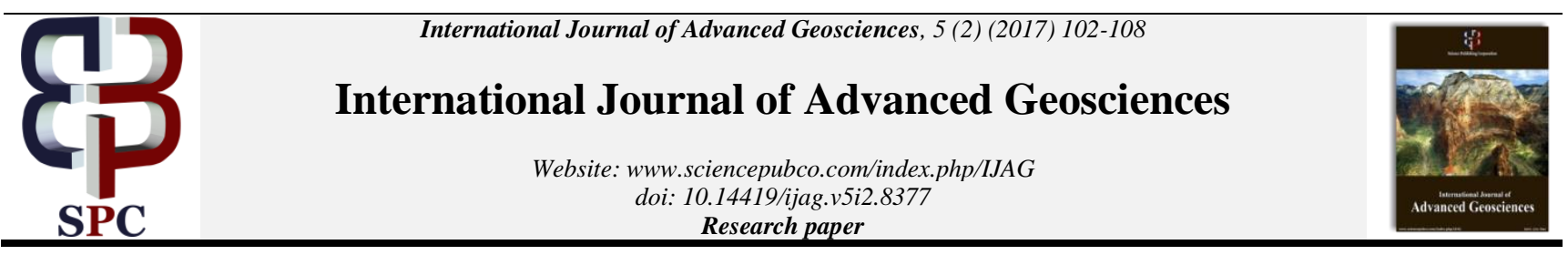

\title{
Geochemical Characteristics and Petrogenesis of Basement Rocks in Idoani Area, Ondo State, Southwestern Nigeria
}

\author{
Adegbuyi, O. ${ }^{1}$, Ogunyele, A. C. ${ }^{1}{ }^{*}$, Odindu, M. ${ }^{2}$, Erinfolami, T. G. ${ }^{1}$ \\ ${ }^{1}$ Department of Earth Sciences, Adekunle Ajasin University, P.M.B. 001, Akungba-Akoko, Ondo State, Nigeria \\ ${ }^{2}$ Department of Geological Sciences, Achievers University, Owo, Ondo State, Nigeria \\ *Corresponding Author's e-mail: abimbola.ogunyele@aaua.edu.ng
}

\begin{abstract}
Idoani area of Ondo State is an extension of the Upper Proterozoic Igarra Schist Belt of the Southwestern Nigerian Basement Complex. The area comprises mainly of metasedimentary rocks with subordinate amount of intrusives. Quartz-mica schist, phyllite, quartzite and banded gneiss are the dominant rock types in the area. These metasediments are intruded by the Older granite and other minor intrusives (pegmatite, aplite, dolerite dyke, quartz vein). Idoani rocks, as revealed by petrographic studies, are rich in quartz, alkali and plagioclase feldspars and mica with a low amount of opaque minerals. Geochemical studies and petrochemical variation diagrams show that the rocks are sub-alkaline, medium-K calc-alkaline to shoshonitic, peraluminous, and characterized by intermediate-high silica content and low-moderate amount of mafic oxides. Petrological and geochemical studies revealed that the quartz-mica schist and phyllite are metapelites while the quartzite is a meta-arkose, derived from a granitic - quartz-monzonitic source. The banded gneisses were probably derived from a hybrid sedimentary-igneous protoliths while the granite is of magmatic origin.
\end{abstract}

Keywords: Geochemical; Intrusive; Metasedimentary; Petrographic; Proterozoic.

\section{Introduction}

The Basement Complex rocks of Idoani area in Ondo State consist mainly of low to medium grade metasediments intruded by minor amount of intrusives. The metasediments of the area are the lateral equivalents of the Igarra metasediments on the west (Fig. 1). The Igarra metasediments, which form a supracrustal cover on the Migmatite-Gneiss Complex, comprises of metapelites (slates, phyllites and schists), psammites, quartzites, metaconglomerates, paragneisses, and carbonates (marble and calc-silicate gneisses) (Odeyemi, 1988; Okeke, et al., 1988; Ocan et al., 2003; Obasi, 2012). The western part of the schist belt, of which Idoani and Owo areas form part, comprises mainly of metapelites (quartzmica schist and phyllite), quartzite, banded gneiss and granitic intrusives (Fig. 2).

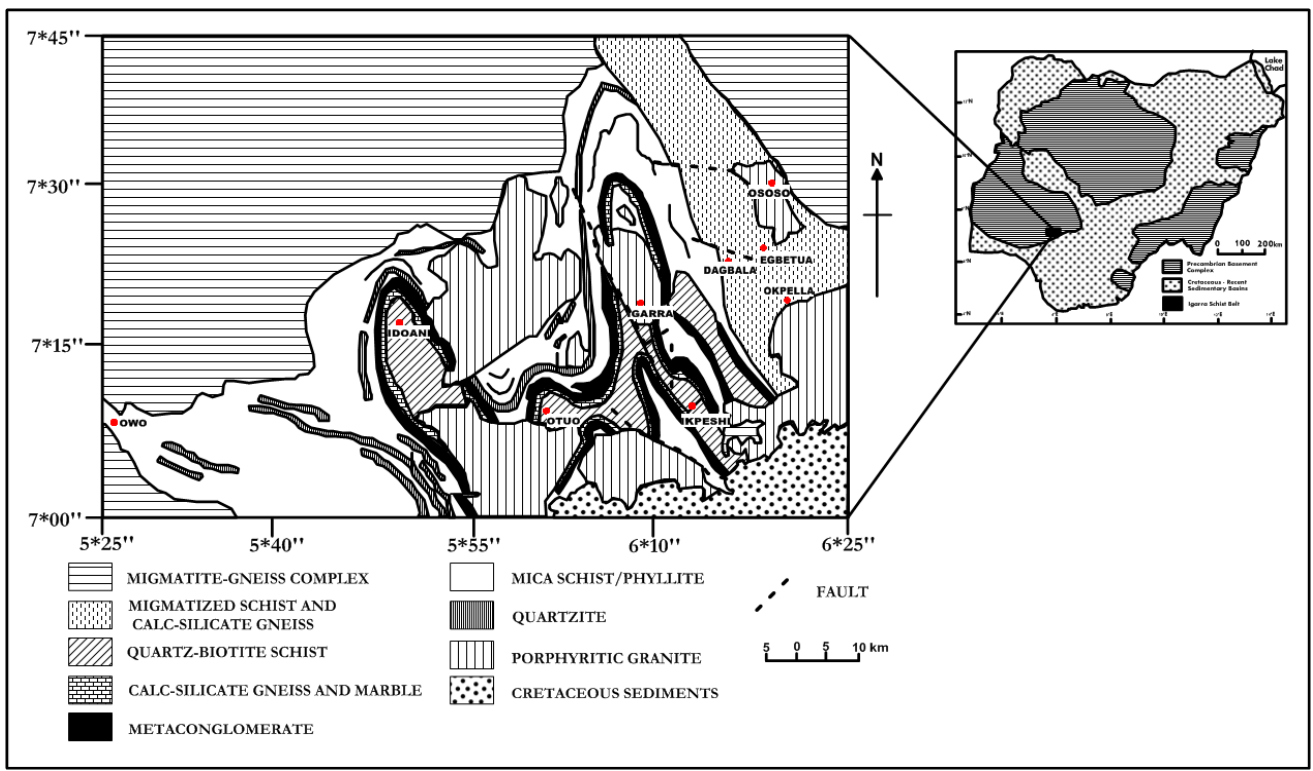

Fig. 1: Geological Map of Igarra Schist Belt showing Idoani area (after Odeyemi, 1988) 


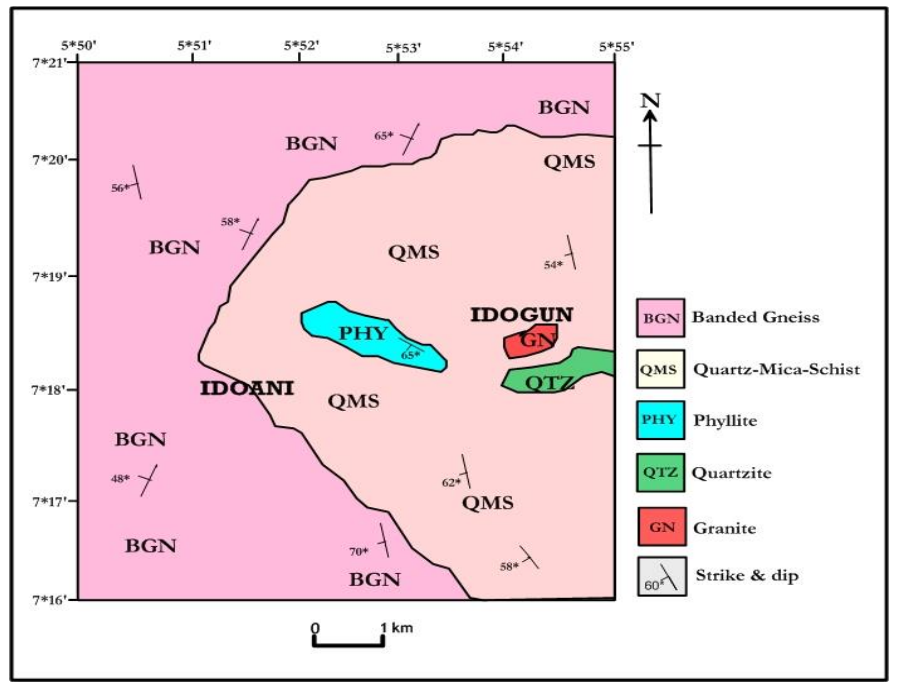

Fig. 2: Geological Map of Idoani area (after Adegbuyi et al., 2015)

\section{Methodology}

Detailed geological mapping and sampling of the rocks throughou the study area (Idoani - Idogun area) were carried out. Sixteen (16) representative whole rock samples comprising of six (6) banded gneiss, two (2) quartz-mica schist, two (2) quartzite, three (3) phyllite and three (3) granite were collected for the purpose of petrographic and geochemical studies. Thin sections of all the samples were prepared and studied under a petrographic microscope. Modal compositions of the rock samples were determined, and photomicrographs were captured. Energy Dispersive X-ray Fluorescence spectrometer (ED-XRF) was used to determine the major elements present in the rocks. Detailed processes of the methods of study are contained in Erinfolami (2009) and Odindu (2015). The results were interpreted using geochemical indices and discrimination diagrams for petrological classification, determination of chemical affinities and petrogenesis

\section{Results and Discussion}

\subsection{Petrology, Mineralogy and Field Relationships}

The main petrological units occurring in Idoani area include: quartz-mica schist, quartzite, phyllite, and banded gneiss. These rocks trend approximately north-south (NS) which is characteristic of Upper Proterozoic Schist Belts of the Nigerian Basement Complex (Rahaman, 1976; Turner, 1983; Elueze and Okunlola, 2003). Other rocks found in the area include granite, pegmatite, quartz vein, aplite and dolerite dykes, which intrude into the former rock units through pre-existing fractures.

The banded gneiss (BGN) is the predominant rock type in Idoani constituting over $50 \%$ of the area (Fig. 2). The gneiss is made up of well-developed bands of both quartzo-feldspathic and ferromagnesian compositions (Fig. 3). The quartzo-feldspathic bands, rich in quartz and feldspars, are whitish - pinkish in colour while the dark-grey ferromagnesian-rich bands are composed mainly of biotite, hornblende and opaque minerals. The bands are sometimes intricately folded and sheared. Numerous joints mostly trending NS and E-W and strike-slip faults are observable on the gneiss.

Quartz-mica schist (QMS) is the second most abundant rock type in the area making up over $45 \%$ of the study area. They are coarse-grained and very rich in quartz, muscovite, biotite, plagioclase, and microcline with accessory opaque minerals (Fig. 4). The quartz-mica schist forms extensive ridges in areas where they are associated with quartzite. In other areas, they have been weathered to a considerable extent and therefore, occur as low-lying outcrops with reddish coloration. Thin bands of massive and foliated quartzite (QTZ) outcrop in the eastern part of Idoani interbanded with quartz-mica schist. The massive quartzite (Fig. 5) contains mainly quartz while the foliated variety contains orthoclase feldspar in addition to quartz. The contact between the quartzite and quartz-mica schist is often gradational marked by lack of foliation in the massive quartzite and increase in the amount of quartz in the foliated quartzite.

Phyllite (PHY) was also found in Idoani along Idoani - Idogun road (Fig. 6). In this area, quartz-mica schist was observed to grade into phyllite marked by reduction to the grain size of the latter. The colour of the phyllite is whitish - buff grey, and it is rich in quartz, microcline, muscovite, and biotite. The phyllite is of local aerial extent and occupies the central part within the study area.

The granitic rocks (GN) of Idoani area occur as intrusions into the metasediments (quartz-mica schist). They are more abundant around Idogun and Imeri and are similar in texture and composition to the Igarra pluton. Hence, they are thought to have been formed at the same time. The granites are coarse to porphyritic in texture, light coloured, and composed mainly of quartz, orthoclase, plagioclase, and biotite. They occur as prominent hills in the area and exhibit sharp contacts with their country rock. Pegmatite, quartz veins, aplites and dolerite dykes are abundant in the area, often cross-cutting the metasediments, granites and themselves (Fig. 7). They are the youngest rocks in the area due to their crosscutting relationship with other rock units.

The modal compositions of Idoani rocks are shown in Table 1. The QAP diagram (Streckeisen, 1976) revealed that Idoani banded gneiss and granite are granitic in composition (Fig. 8).

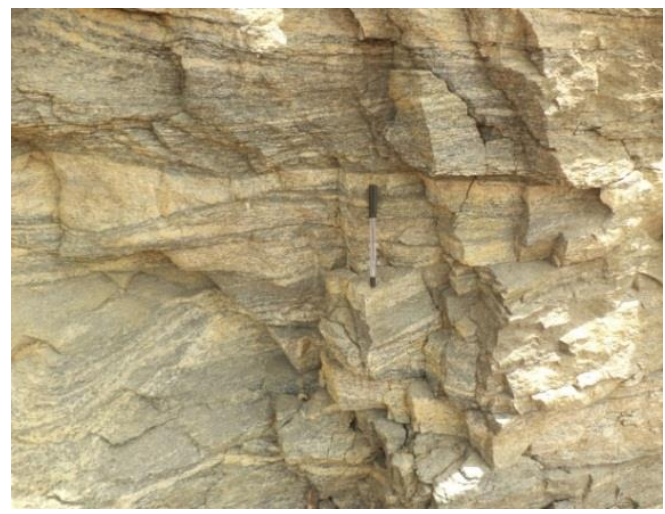

Fig. 3: Banded Gneiss 


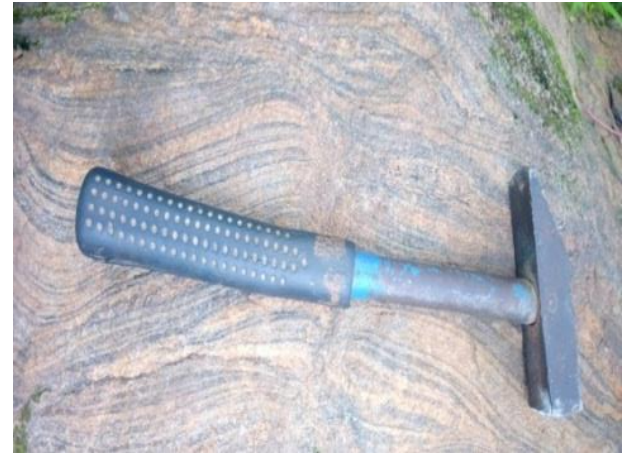

Fig. 4: Quartz-mica schist

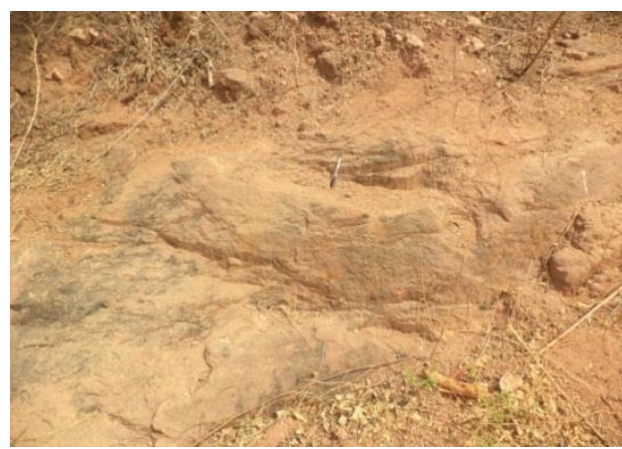

Fig. 5: Quartzite

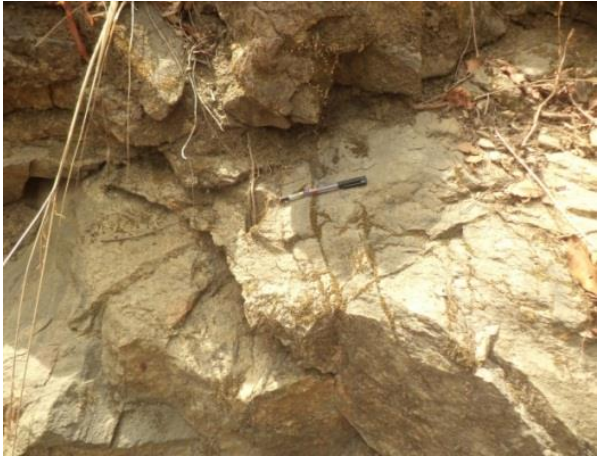

Fig. 6: Phyllite

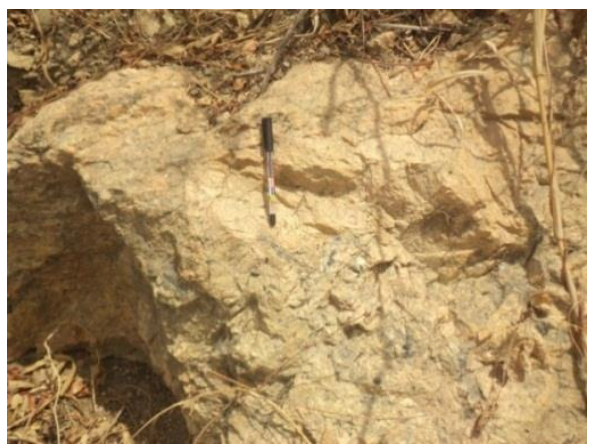

Fig. 6: Pegmatite intruded into Banded Gneiss in Idoan

Table 1: Modal Compositions of Idoani rocks (Values in Wt. \%)

\begin{tabular}{|c|c|c|c|c|c|c|c|c|c|c|c|c|c|c|c|c|}
\hline \multirow{2}{*}{ Minerals } & \multicolumn{5}{|c|}{ Banded Gneiss } & \multicolumn{4}{|c|}{$\begin{array}{l}\text { Quartz-Mica } \\
\text { Schist }\end{array}$} & \multicolumn{2}{|l|}{ Phyllite } & \multicolumn{2}{|c|}{ Quartzite } & \multicolumn{3}{|c|}{ Granite } \\
\hline & BGN1 & BGN2 & BGN3 & BGN4 & BGN5 & BGN6 & QMS1 & QMS2 & PHY1 & PHY2 & PHY3 & QTZ1 & QTZ2 & GN1 & GN2 & GN3 \\
\hline Quartz & 37.36 & 37.00 & 35.89 & 42.16 & 38.20 & 33.65 & 41.40 & 38.6 & 51.44 & 46.50 & 48.10 & 95.11 & 85.57 & 29.73 & 31.10 & 29.68 \\
\hline Plagioclase & 14.29 & 11.10 & 3.85 & 19.65 & 18.65 & 18.43 & 7.60 & 8.70 & 1.44 & 3.15 & 3.87 & --- & --- & 12.16 & 22.71 & 18.38 \\
\hline Microcline & --- & 16.30 & 38.46 & 16.82 & --- & --- & 13.50 & 13.90 & 15.87 & 13.71 & 11.52 & --- & --- & 40.54 & --- & --- \\
\hline Orthoclase & 10.98 & 8.20 & --- & 1.14 & 18.68 & 20.78 & --- & --- & --- & --- & --- & 3.10 & 11.20 & 4.05 & 22.58 & 20.80 \\
\hline Biotite & 37.36 & 22.50 & 15.38 & 14.20 & 16.83 & 17.52 & 8.70 & 17.60 & 13.94 & 12.35 & 16.10 & --- & --- & 13.51 & 17.80 & 22.95 \\
\hline Muscovite & --- & --- & --- & --- & --- & --- & 19.90 & 17.00 & 15.87 & 19.53 & 18.78 & 1.30 & 3.86 & --- & --- & --- \\
\hline Opaques & --- & 6.10 & 6.43 & 5.68 & 7.65 & 8.88 & 8.80 & 4.10 & 1.42 & 3.87 & 1.54 & 0.64 & 1.21 & --- & 5.70 & 8.00 \\
\hline Total & 99.99 & 101.2 & 100.01 & 99.65 & 99.99 & 99.26 & 99.90 & 99.90 & 99.98 & 99.11 & 99.91 & 100.15 & 101.84 & 99.99 & 99.89 & 99.81 \\
\hline
\end{tabular}

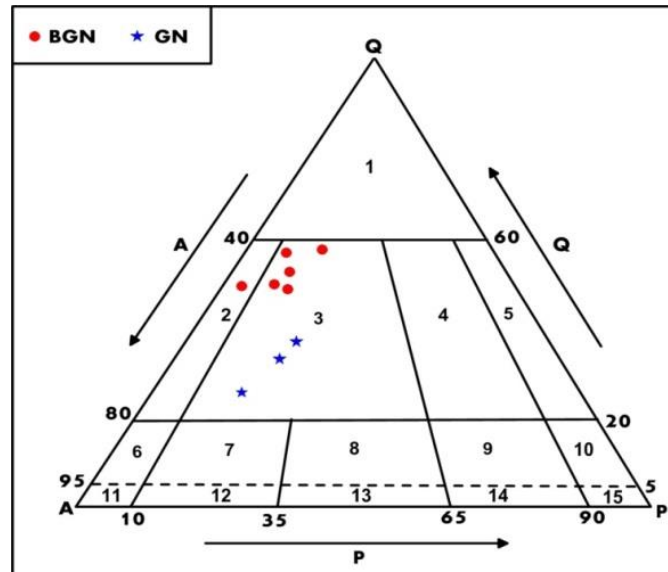

Fig. 8: QAP diagram for Idoani granite and banded gneiss (after Streckeisen, 1976)

1=Not Igneous; 2=Alkali Granite; 3=Granite; 4=Granodiorite; 5=Tonalite; 6=Alkali Quartz Syenite; 7=Quartz Syenite; 8=Quartz Monzonite; 9=Quartz Monzodiorite; 10=Quartz Diorite; 11=Alkali Syenite; 12=Syenite; 13=Monzonite; 14=Monzodiorite; 15=Diorite. 


\subsection{Geochemistry and Petrogenesis}

The chemical composition of Idoani rocks is shown in Table 2.

Table 2: Chemical Compositions of Idoani Rocks (Values in Wt. \%)

\begin{tabular}{|c|c|c|c|c|c|c|c|c|c|c|c|c|c|c|c|c|}
\hline \multirow{2}{*}{$\begin{array}{l}\text { Major } \\
\text { Oxides }\end{array}$} & \multicolumn{5}{|c|}{ Banded Gneiss } & \multicolumn{4}{|c|}{$\begin{array}{c}\text { Quartz-Mica } \\
\text { Schist }\end{array}$} & \multicolumn{2}{|l|}{ Phyllite } & \multicolumn{2}{|c|}{ Quartzite } & \multicolumn{3}{|c|}{ Granite } \\
\hline & BGN1 & BGN2 & BGN3 & BGN4 & BGN5 & BGN6 & QMS1 & QMS2 & PHY1 & PHY2 & PHY3 & QTZ1 & QTZ2 & GN1 & GN2 & GN3 \\
\hline $\mathrm{SiO}_{2}$ & 67.45 & 65.31 & 63.18 & 65.11 & 66.12 & 68.00 & 69.68 & 68.10 & 62.54 & 64.12 & 66.50 & 79.11 & 71.70 & 68.01 & 63.05 & 64.98 \\
\hline $\mathrm{TiO}_{2}$ & 0.44 & 0.79 & 0.46 & 0.73 & 0.32 & 0.56 & 0.21 & 0.24 & 0.44 & 0.42 & 0.38 & 0.32 & 0.47 & 0.42 & 0.30 & 0.22 \\
\hline $\mathrm{Al}_{2} \mathrm{O}_{3}$ & 15.34 & 16.21 & 14.25 & 16.85 & 19.12 & 14.82 & 13.56 & 12.64 & 15.32 & 17.69 & 14.33 & 7.06 & 12.48 & 14.32 & 17.44 & 16.38 \\
\hline $\mathrm{Fe}_{2} \mathrm{O}_{3}$ & 2.34 & 3.21 & 2.17 & 2.67 & 0.91 & 0.92 & 7.72 & 7.58 & 8.63 & 6.99 & 6.65 & 4.01 & 3.98 & 2.84 & 0.79 & 0.71 \\
\hline $\mathrm{FeO}$ & 1.38 & 1.89 & 1.28 & 1.58 & 1.62 & 1.60 & 1.58 & 1.78 & 1.96 & 0.98 & 0.95 & 0.80 & 0.78 & 1.68 & 1.70 & 1.77 \\
\hline $\mathrm{MnO}$ & 0.05 & 0.10 & 0.06 & 0.10 & 0.05 & 0.08 & 0.01 & 0.04 & 0.05 & 0.06 & 0.08 & 0.12 & 0.11 & 0.05 & 0.08 & 0.09 \\
\hline $\mathrm{MgO}$ & 2.54 & 1.24 & 3.14 & 1.24 & 2.09 & 2.09 & 0.16 & 1.18 & 0.64 & 1.12 & 1.11 & 1.31 & 1.28 & 2.31 & 2.10 & 2.17 \\
\hline $\mathrm{CaO}$ & 1.11 & 2.35 & 1.62 & 1.26 & 1.00 & 2.00 & 1.01 & 1.00 & 1.24 & 0.54 & 1.00 & 1.56 & 1.52 & 1.76 & 2.00 & 1.92 \\
\hline $\mathrm{Na}_{2} \mathrm{O}$ & 2.41 & 2.15 & 2.15 & 3.46 & 3.02 & 4.00 & 1.20 & 1.19 & 2.34 & 2.40 & 2.49 & 1.21 & 2.77 & 2.54 & 4.50 & 3.63 \\
\hline $\mathrm{K}_{2} \mathrm{O}$ & 3.10 & 3.30 & 1.85 & 3.30 & 4.00 & 1.20 & 2.30 & 2.21 & 2.67 & 3.49 & 3.50 & 2.49 & 3.81 & 3.21 & 5.85 & 5.76 \\
\hline $\mathrm{P}_{2} \mathrm{O}_{5}$ & 0.30 & 0.33 & 0.31 & 0.33 & 0.34 & 0.33 & 0.31 & 0.29 & 0.15 & 0.17 & 0.15 & 0.12 & 0.13 & 0.12 & 0.11 & 0.10 \\
\hline LOI & 2.64 & 3.64 & 4.14 & 3.45 & 1.62 & 1.45 & 2.52 & 3.63 & 4.00 & 1.87 & 2.84 & 1.79 & 1.04 & 2.84 & 2.10 & 2.02 \\
\hline TOTAL & 99.10 & 100.52 & 99.61 & 100.16 & 100.09 & 100.04 & 100.26 & 99.88 & 99.98 & 99.850 & 99.98 & 99.90 & 100.07 & 100.10 & 99.98 & 99.80 \\
\hline
\end{tabular}

The geochemistry of the rocks reveals the following:

1) Intermediate - high silica content (Banded gneiss: $65-68 \%$ $\mathrm{SiO}_{2}$; Quartz-mica schist: 68-70\% $\mathrm{SiO}_{2}$; Phyllite: 62-66\% $\mathrm{SiO}_{2}$; Quartzite: $71-79 \% \mathrm{SiO}_{2}$; Granite: $63-68 \% \mathrm{SiO}_{2}$ ). This reflects the quartzo-feldspathic nature of all the rocks.

2) High $\mathrm{Al}_{2} \mathrm{O}_{3}$ content (except in quartzite) as a result of high amount of feldspars. This reflects the pelitic nature of the banded gneiss, phyllite, and quartz-mica schist.

3) Low - moderate $\mathrm{CaO}, \mathrm{FeO}, \mathrm{Fe}_{2} \mathrm{O}_{3}$ and $\mathrm{MgO}$ contents except in the quartz-mica schist. This reflects the low content of ferromagnesian minerals in the rocks except micas (biotite + muscovite) which are considerably high and defines the foliation in the banded gneiss, schist and phyllite. Enrichment in $\mathrm{SiO}_{2}$ coupled with impoverishment in $\mathrm{CaO}$ and $\mathrm{MgO}$ indicates the quartz-mica schist, phyllite, quartzite and banded gneiss to be metasediments (Ekwueme and Kroner, 1997).

4) Moderate amounts of $\mathrm{K}_{2} \mathrm{O}$ and $\mathrm{Na}_{2} \mathrm{O}$ content due to the high amount of K-feldspars and plagioclase.

These characteristics suggest that the rocks are intermediate to silicic in composition and richer in felsic minerals (particularly quartz and feldspars) than ferromagnesian minerals.

On the discrimination diagram of Garrels and McKenzie (1971) (Fig. 9), the quartz-mica schist, quartzite and phyllite plot within the sedimentary/metasedimentary sedimentary field, the granite samples plot in the igneous field while the banded gneiss samples plot in both sedimentary and igneous fields particularly at the boundary between the two fields. This shows that the quartz-mica schist, quartzite and phyllite are of sedimentary origin, the granite is of magmatic origin while the banded gneiss is of hybrid or mixed origin (sedimentary and igneous protoliths). These gneisses are similar in composition and petrochemical affinity to the gneisses from Kabba-Lokoja area, hence they are thought to be of similar origin, that is, they were derived from a hybrid sedimentary-igneous protoliths, most probably in the form of a sedimentary geosynclinal pile interstratified with intermediate to silicic hyperbyssal igneous rocks (Odigi and Ezepue, 1993).

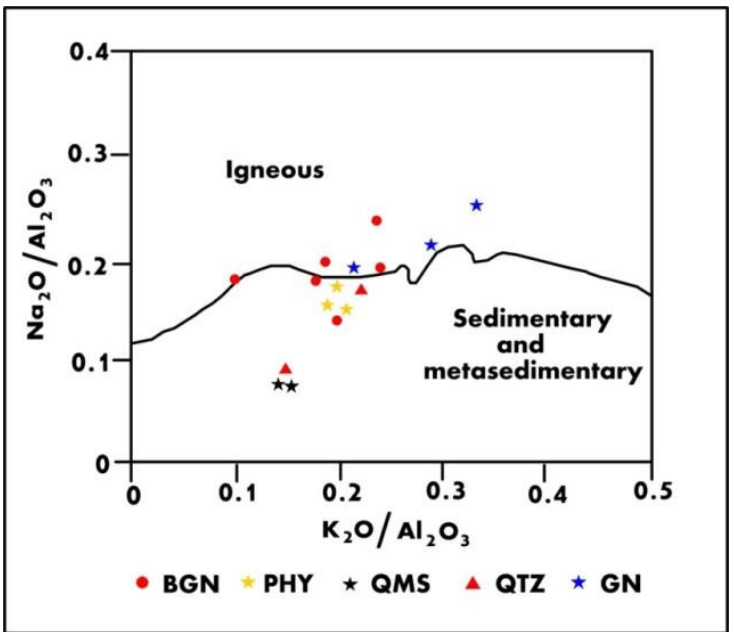

Fig. 9: $\mathrm{Na}_{2} \mathrm{O} / \mathrm{Al}_{2} \mathrm{O}_{3}$ versus $\mathrm{K}_{2} \mathrm{O} / \mathrm{Al}_{2} \mathrm{O}_{3}$ discrimination diagram for Idoani basement rocks (after Garrels and McKenzie, 1971)

The $\mathrm{MgO}-\mathrm{CaO}-\mathrm{Al}_{2} \mathrm{O}_{3}$ diagram (Leyleroup, et al., 1977) (Fig. 10) confirms the sedimentary origin of the quartz-mica schist, quartzite and phyllite as these rocks plot outside the magmatic field. The banded gneiss plots both within and outside the magmatic field while the granite plots in the magmatic field. The granite samples plot outside the eugeosynclinal sandstone field on the $\mathrm{K}_{2} \mathrm{O}$ versus $\mathrm{Na}_{2} \mathrm{O}$ discrimination diagram of Middleton (1960) indicating their non-sedimentary (igneous) origin while four (4) of the banded gneiss samples plot in the eugeosynclinal sandstone field and two (2) samples plot outside the field (Fig. 11). This also confirms the mixed origin of the banded gneiss as revealed by the plots of Garrels and McKenzie (1971) and Leyleroup, et al. (1977). All the quartz-mica schist, quartzite and phyllite samples plot within the eugeosynclinal sandstone field. Eugeosynclinal sandstones are the graywackes of Pettijohn (1957) (Ekwueme and Kroner, 1997; Ekwueme, 1997). This therefore confirms that these rocks were derived from sedimentary protoliths. 


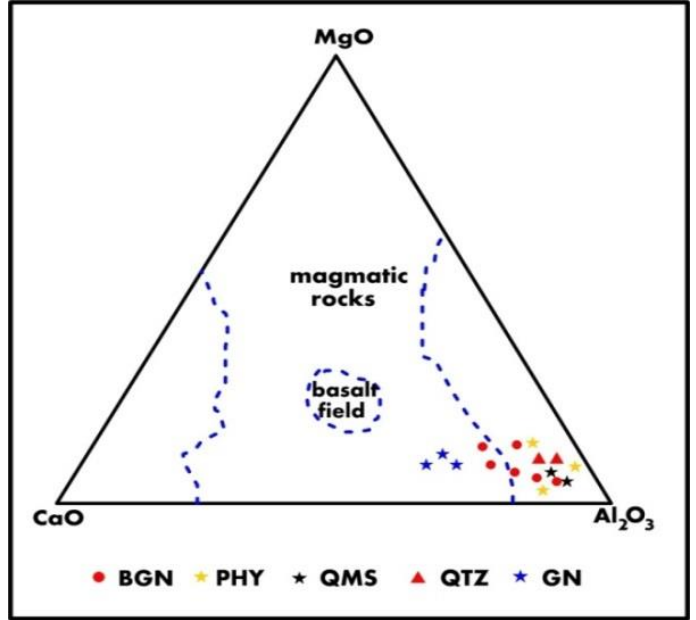

Fig. 10: $\mathrm{MgO}-\mathrm{CaO}-\mathrm{Al}_{2} \mathrm{O}_{3}$ diagram for rocks in Idoani area (after Leyleroup et al., 1977)

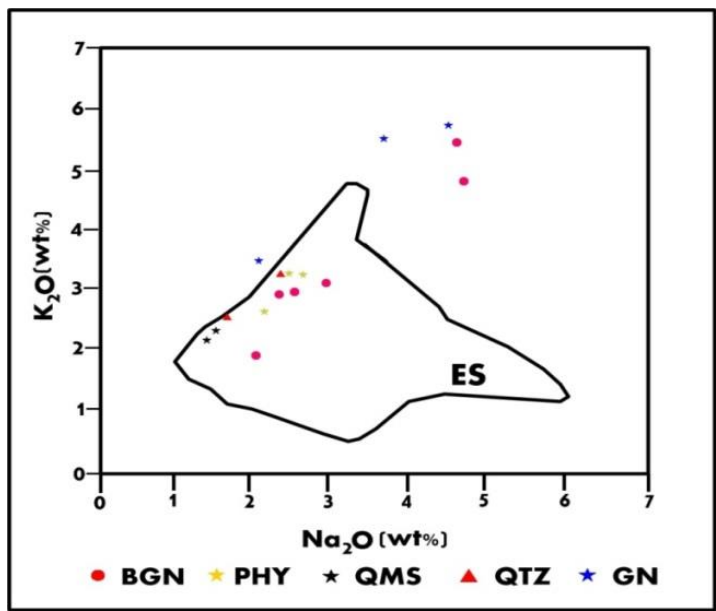

Fig. 11: $\mathrm{K}_{2} \mathrm{O}$ versus $\mathrm{Na}_{2} \mathrm{O}$ discrimination diagram for rocks in Idoani area (after Middleton, 1960)

In the ACF diagram of Winkler (1967), the quartz-mica schist and phyllite plot in the field of pelitic rocks while the quartzite and banded gneiss plot as quartzo-feldspathic rocks (Fig. 12). When the quartz-mica schist, phyllite and quartzite are plotted on the $\mathrm{CaO}-\mathrm{Na}_{2} \mathrm{O}-\mathrm{K}_{2} \mathrm{O}$ diagram (Fig. 13), and the fields showing the compositional variations in acid to basic rocks are superimposed (Condie, 1967), they plot in the field of granite - quartzmonzonite, indicating that their shale-arkose protoliths were derived essentially from a granitic - quartz-monzonitic source.

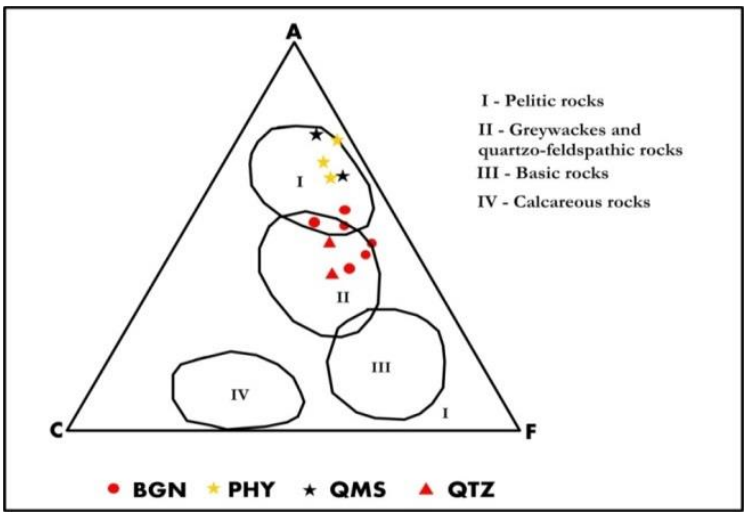

Fig. 12: ACF diagram for rocks in Idoani area (modified after Winkler, 1967)

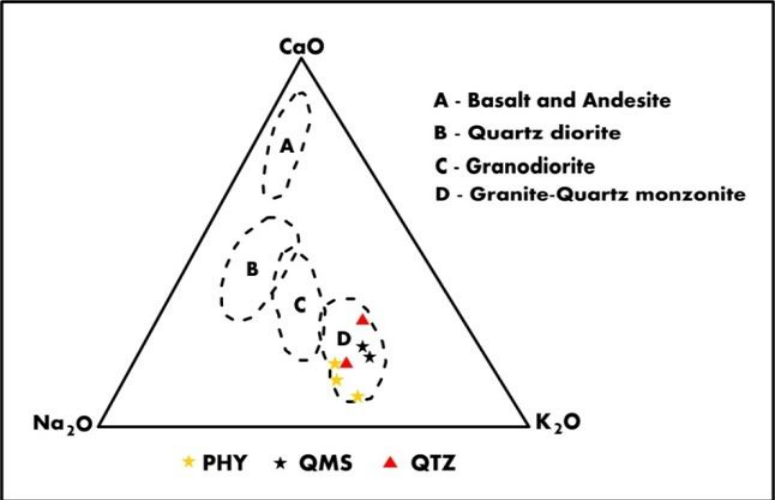

Fig. 13: $\mathrm{CaO}-\mathrm{Na}_{2} \mathrm{O}-\mathrm{K}_{2} \mathrm{O}$ ternary diagram for metasedimentary rocks in Idoani area (after Condie, 1967)

The discrimination plot of Irvine and Baragar (1971) show that all the rocks are sub-alkaline (Fig. 14). Idoani rocks are peraluminous as shown on the $\mathrm{Al}_{2} \mathrm{O}_{3} /\left(\mathrm{Na}_{2} \mathrm{O}+\mathrm{K}_{2} \mathrm{O}\right)$ against $\mathrm{Al}_{2} \mathrm{O}_{3} /\left(\mathrm{Na}_{2} \mathrm{O}+\right.$ $\mathrm{K}_{2} \mathrm{O}+\mathrm{CaO}$ ) molecular diagram of Maniar and Piccoli, 1989 (Fig. 15). Their peraluminous nature coupled with intermediate - high silica content reveals that the rocks of Idoani area were derived from crustal sources (Taylor and McLennan, 1981; Frost et al., 2001). Idoani banded gneisses and granites were plotted on the $\mathrm{Al}_{2} \mathrm{O}_{3} /\left(\mathrm{CaO}+\mathrm{Na}_{2} \mathrm{O}+\mathrm{K}_{2} \mathrm{O}\right)$ versus $\mathrm{SiO}_{2}$ plot (Dombrowski et al., $1995)$ to determine their granitoid type(s). The granites plot mainly as I-type granitoid and the banded gneiss as S-type granitoids (Fig. 16). This suggests that the granites were derived from partial melting of igneous rocks while the igneous protolith of the banded gneisses were derived from the partial melting of sedimentary rocks within the crust.

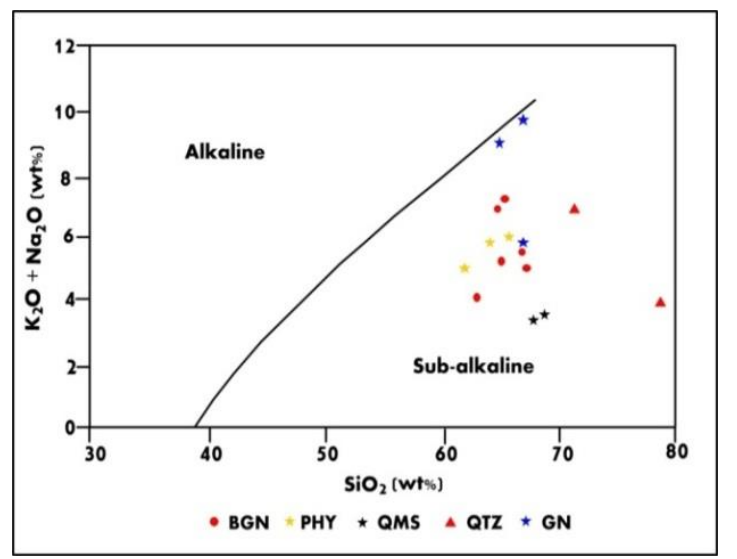

Fig. 14: $\mathrm{Na}_{2} \mathrm{O}+\mathrm{K}_{2} \mathrm{O}$ against $\mathrm{SiO}_{2}$ Plot for rocks in Idoani area (after Irvine and Baragar, 1971)

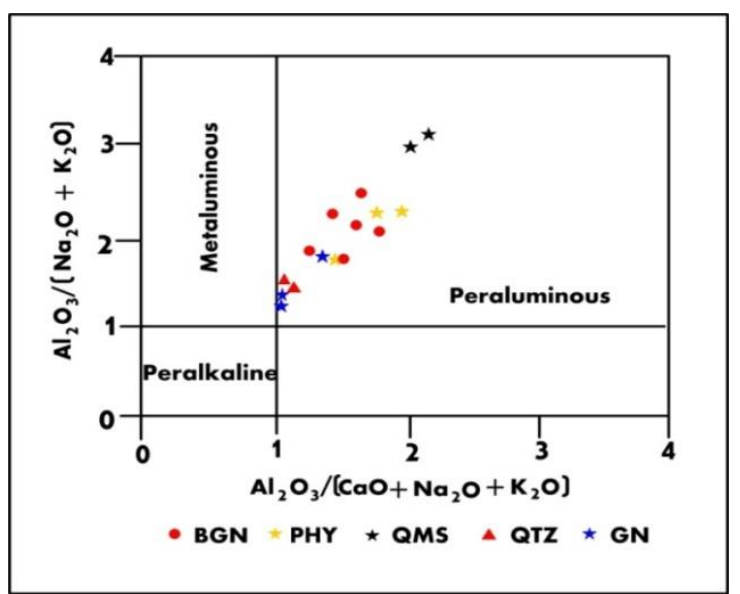

Fig. 15: $\mathrm{Al}_{2} \mathrm{O}_{3} /\left(\mathrm{Na}_{2} \mathrm{O}+\mathrm{K}_{2} \mathrm{O}\right)$ versus $\mathrm{Al}_{2} \mathrm{O}_{3} /\left(\mathrm{CaO}+\mathrm{Na}_{2} \mathrm{O}+\mathrm{K}_{2} \mathrm{O}\right)$ molecular plot for rocks in Idoani area (after Maniar and Piccoli, 1989) 


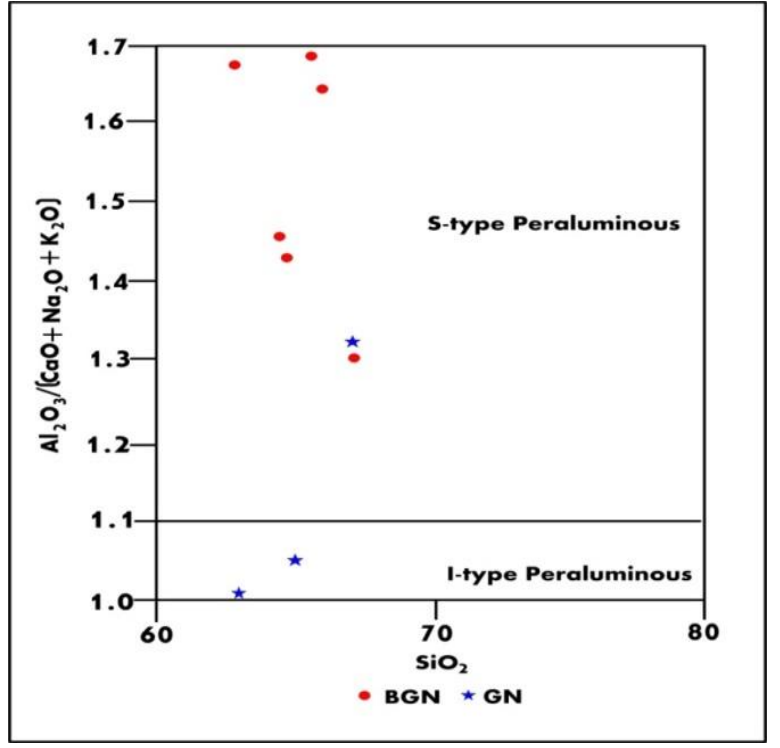

Fig. 16: $\mathrm{Al}_{2} \mathrm{O}_{3} /\left(\mathrm{CaO}+\mathrm{Na}_{2} \mathrm{O}+\mathrm{K}_{2} \mathrm{O}\right)$ versus $\mathrm{SiO}_{2}$ plot for rocks in Idoani area (after Dombrowski et al., 1995)

On the $\mathrm{K}_{2} \mathrm{O}$ versus $\mathrm{SiO}_{2}$ plot (Rickwood, 1989), the granites plot dominantly in the shoshonitic field while the banded gneiss, quartzite, quartz-mica schist and phyllite are medium - high-K calc-alkaline rocks (Fig. 17). Shoshonitic and high-K calc-alkaline rocks have been found in some areas to be associated with goldcopper mineralization (Joplin, 1968). The geological settings as well as geochemical characteristics of Idoani rocks as highlighted in this work also suggests the possibility of gold mineralization in the study area. Hence, detailed soil and stream sediment geochemical exploration for gold in the area is encouraged.

Comparism of the geology and composition of the metasediments and granite of Idoani area with those from Igarra (Okeke and Meju, 1998) (Table 3) show that they are chemically similar and hence, Idoani area is an extension of the Igarra Schist Belt. Based on field relationships, metamorphic grade and structures, the banded gneiss of Idoani area is believed to be older than the quartz-mica schist and phyllite (metapelites) and quartzite (metaarkose). This is in concordance with the lithostratigraphy of the Igarra Schist Belt (Odeyemi, 1988).

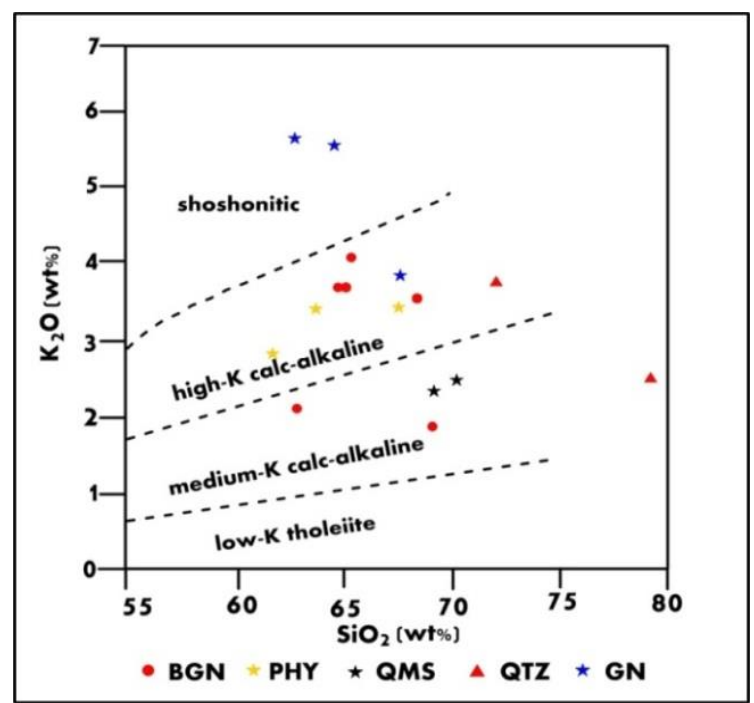

Fig. 17: $\mathrm{K}_{2} \mathrm{O}$ versus $\mathrm{SiO}_{2}$ plot for rocks in Idoani area (after Rickwood, 1989)

\section{Conclusion}

The petrology and geochemistry of the rocks in Idoani area indicate sedimentary protoliths for the quartz-mica schist, phyllite and quartzite. The quartz-mica schist and phyllite are metapelites while the quartzite is considered a meta-arkose derived from a granitic - quartz-monzonitic source. The banded gneisses were derived from hybrid sedimentary-igneous protoliths (arkosic rocks mixed with intermediate to silicic hyperbyssal igneous rocks) while the granite is of magmatic origin. The igneous protoliths of the banded gneisses are S-type granitoids while the granites are Itype granitoids suggesting that they were most probably derived from partial melting of crustal sedimentary and igneous rocks respectively.

Table 3: Comparism of the chemical compositions of some rocks of Igarra and Idoani areas

\begin{tabular}{|c|c|c|c|c|c|c|c|c|}
\hline \multicolumn{5}{|c|}{$\begin{array}{l}\text { Chemical composition of some rocks in the Igarra Schist Belt } \\
\text { (Okeke and Meju, 1998) }\end{array}$} & \multicolumn{4}{|c|}{$\begin{array}{l}\text { Chemical composition of some Idoani rocks } \\
\text { (This study) }\end{array}$} \\
\hline $\begin{array}{l}\text { MAJOR } \\
\text { OXIDES } \\
(w t \%)\end{array}$ & $\begin{array}{l}\text { MICA- } \\
\text { SCHIST } \\
(\mathrm{N}=8)\end{array}$ & $\begin{array}{c}\text { PHYLLITIC } \\
\text { SCHIST } \\
(\mathrm{N}=9)\end{array}$ & $\begin{array}{l}\text { QUARTZITE } \\
\qquad(\mathrm{N}=8)\end{array}$ & $\begin{array}{l}\text { GRANITE } \\
(\mathrm{N}=8)\end{array}$ & $\begin{array}{c}\text { QUARTZ- } \\
\text { MICA } \\
\text { SCHIST } \\
(\mathrm{N}=2)\end{array}$ & $\begin{array}{l}\text { PHYLLITE } \\
\qquad(\mathrm{N}=3)\end{array}$ & $\begin{array}{l}\text { QUARTZITE } \\
\qquad(\mathrm{N}=2)\end{array}$ & $\begin{array}{l}\text { GRANITE } \\
(\mathrm{N}=3)\end{array}$ \\
\hline $\mathrm{SiO}_{2}$ & 69.70 & 67.00 & 73.00 & 66.00 & 68.89 & 64.39 & 75.41 & 65.35 \\
\hline $\mathrm{Al}_{2} \mathrm{O}_{3}$ & 14.84 & 16.51 & 15.00 & 18.00 & 13.10 & 15.78 & 9.77 & 16.05 \\
\hline $\mathrm{Fe}_{2} \mathrm{O}_{3}$ & 7.51 & 6.60 & 3.23 & 0.82 & 7.65 & 7.42 & 4.99 & 1.45 \\
\hline $\mathrm{MgO}$ & 0.69 & 1.12 & 1.33 & 2.00 & 0.67 & 0.96 & 1.30 & 2.19 \\
\hline $\mathrm{CaO}$ & 1.00 & 0.91 & 1.00 & 1.92 & 1.01 & 0.93 & 1.54 & 1.89 \\
\hline $\mathrm{Na}_{2} \mathrm{O}$ & 1.18 & 2.47 & 1.67 & 3.66 & 1.19 & 2.41 & 1.99 & 3.56 \\
\hline $\mathrm{K}_{2} \mathrm{O}$ & 3.80 & 3.39 & 3.90 & 6.20 & 2.26 & 3.22 & 3.51 & 4.94 \\
\hline TOTAL & 98.72 & 98.06 & 99.22 & 98.66 & 94.80 & 95.17 & 98.63 & 95.50 \\
\hline
\end{tabular}

\section{References}

[1] Adegbuyi, O., Adeleye, B. O. and Ogunyele, A. C. (2015): Evaluation of the physical and chemical properties of lateritic soils from Idoani area, Ondo State, Southwestern Nigeria. Achievers Journal of Scientific Research, Vol. 1, No. 1, pp. 25-31.s

[2] Condie, K. C. (1967): Geochemistry of early Precambrian greywackes from Wyoming. Geochim.Comochim.Acta, Vol. 31, pp. 2135-2149.https://doi.org/10.1016/0016-7037(67)90057-9.
[3] Dombrowski, A., Henjes-Kunst, F., Hohndorf, A., Kroener, A., Okrusch, M., and Richter, P. (1995): Orthogneisses in the Sperssart Crystalline Complex, north-west Bavaria: Silurian granitoidmagmatism at an active continental margin. Geol. Rundsch. Vol. 84, pp 399-411. https://doi.org/10.1007/s005310050014.

[4] Ekwueme, B. N. (2003): The Precambrian Geology and Evolution of the Southeastern Nigerian Basement Complex. University of Calabar Press. 135 p.

[5] Ekwueme, B. N. and Kroner, A. (1997): Zircon evaporation ages and Chemical Composition of a Migmatitic Schist in the Obudu Plateau: evidence for Paleoproterozoic (ca. $1789 \mathrm{Ma}$ ) component in 
the Basement Complex of Southeastern Nigeria. Journal of Mining and Geology, Vol. 33, No. 2, pp. 81-88.

[6] Elueze, A. A. and Okunlola, O. A. (2003): Petrochemical and Petrogenetic Characteristics of Metasedimentary Rocks of Lokoja Jakura Schist Belt, Central Nigeria. Journal of Mining and Geology, Vol. 39, No. 1, pp. 21-27.

[7] Erinfolami, T. G. (2009): Petrographic and Geochemical Studies of the Basement Complex rocks in Idoani district, Ondo State, Nigeria. Unpublished B.Sc. Dissertation, Dept. of Earth Sciences, AAUA. $94 \mathrm{p}$

[8] Garrel, R. M. and McKenzie, F. T. (1971): Evolution of Sedimentary Rocks. W. W. Norton and Co. Int. New York. 394p.

[9] Irvine, T. N., and Baragar, W. R. A. (1971): A guide to the chemical classifications of the common volcanic rocks. Can. Jour. Earth Sci., Vol. 8, pp. 523-548. https://doi.org/10.1139/e71-055.

[10] Joplin, G. A. (1968): The Shoshonite Association: A Review. Journal of the Geological Soc. of Australia, Vol. 15, No. 2.pp 275-294. https://doi.org/10.1080/00167616808728699.

[11] Leyleroup, A., Duppy, C., and Andriambolona, R. (1977): Chemical composition and consequence of the evolution of the French Massif Central Precambrian crust. Contrib. Mineral Petrol. Vol. 62, pp. 283-300

[12] Maniar, P. D. and Piccoli, P. M. (1989): Tectonic discrimination of granitoids. Geol. Soc. Amer. Bull., Vol. 101, pp. 635-643. https://doi.org/10.1130/00167606(1989)101<0635:TDOG>2.3.CO;

[13] Middleton, E. V. (1960): Chemical Composition of Sandstone. Bull. Geol. Soc. of America, Vol. 71, pp. 1011-1026. https://doi.org/10.1130/0016-7606(1960)71[1011:CCOS]2.0.CO;2.

[14] Obasi, R. A. (2012): Geochemistry and Appraisal of the Economic Potential of Calc-gneiss and Marble from Igarra, Edo State, Southwest, Nigeria. ARPN Journal of Science and Technology, Vol. 2, No. 10, pp. 1018-1021.

[15] Ocan, O., Coker, S. J., and Egbuniwe, I. G. (2003): The Geology of Igarra-Auchi area. Excursion guide at the Annual Conference of the Nigerian Mining and Geosciences Society (NMGS), Itakpe 2003, 52p.

[16] Odeyemi I. B. (1988): Lithostratigraphy and Structural Relationships of the Upper Precambrian Metasediments in Igarra area, Southwestern Nigeria. In: Oluyide, P. O., Mbonu, W. C., Ogezi, A. E. O., Egbuniwe, I. G., Ajibade, A. C. and Umeji, A. C. (Eds.) Precambrian Geology of Nigeria. Geological Survey of Nigeria, Kaduna. pp. 111-125.
[17] Odigi, M. I. and Ezepue, M. C. (1993): Petrochemistry of Gneisses from Kabba - Lokojaarea, Southwestern Nigeria. Journal of Mining and Geology, Vol. 29, No. 1, pp. 41-50.

[18] Odindu, M. (2015): Petrography, Geochemistry and Radioactivity of Rocks in Idoani area, Owo, Ondo State, Nigeria. Unpublished B.Sc. Dissertation, Dept. of Geological Sciences, Achievers University, Owo. 55p.

[19] Okeke, M. A. and Meju, C. A. (1998): Petrography and Major Element Geochemistry of the Basement rocks in Igarra area, Southwestern Nigeria. Chem. Geol., Vol. 58, pp. 35-38.

[20] Okeke, P. O, Akinnagbe, T. and Anike, L. O. (1988): Major and minor element evaluation of the Igarra granite. Journal of Mining and Geology, Vol. 24, No. 1, pp. 101-106.

[21] Pettijohn, F. J. (1957): Sedimentary Rocks. $2^{\text {nd }}$ Ed. Harper \& Row, New York.526 pp.

[22] Rahaman, M. A. (1976): Review of the Basement Geology of Southwestern Nigeria. In: Kogbe, C. A. (Ed.) Geology of Nigeria. Elizabethan Publ. Co. Lagos, pp. 41- 48.

[23] Rickwood, P. C. (1989): Boundary lines within petrologic diagrams which use oxides of major and minor elements. Lithos, Vol. 22, pp. 247-263. https://doi.org/10.1016/0024-4937(89)90028-5.

[24] Streckeisen, A. L. (1976): To each Plutonic Rock its proper Name. Earth Science Rev. 12p. https://doi.org/10.1016/00128252(76)90052-0.

[25] Taylor, S. R. and McLennan, S. M. (1981): The composition and evolution of the continental crust: rare earth elements evidence from sedimentary rocks. Phil. Trans. R. Society of London, Vol. 301 , pp. 381-399. http://www.jstor.org/stable/37026. https://doi.org/10.1098/rsta.1981.0119.

[26] Turner, D. C. (1983): Upper Proterozoic Schist Belts in the Nigerian Sector of the Pan-African Province of West Africa. Precambrian Research, Vol. 21, pp. 55-79. https://doi.org/10.1016/03019268(83)90005-0.

[27] Winkler, H. G. F. (1967): Petrogenesis of Metamorphic Rocks. $2^{\text {nd }}$ Edition. Springer Verlag, New York, 237p. https://doi.org/10.1007/978-3-662-00866-9. 